\title{
Assessing the effects of climate change on flood inundation in the lower Mekong Basin using high-resolution AGCM outputs
}

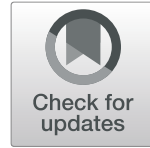

\author{
Sophal Try ${ }^{1,4^{*}} \mathbb{D}$, Shigenobu Tanaka ${ }^{2}$, Kenji Tanaka ${ }^{2}$, Takahiro Sayama ${ }^{2}$, Giha Lee ${ }^{3}$ and Chantha Oeurng ${ }^{4}$
}

\begin{abstract}
Climate change currently affects the resilience and aquatic ecosystem. Climate change alters rainfall patterns which have a great impact on river flow. Annual flooding is an important hydrological characteristic of the Mekong River Basin (MRB) and it drives the high productivity of the ecosystem and biodiversity in the Tonle Sap floodplain and the Mekong Delta. This study aims to assess the impacts of climate change on river flow in the MRB and flood inundation in the Lower Mekong Basin (LMB). The changing impacts were assessed by a two-dimensional rainfallrunoff and inundation model (RRI model). The present climate (1979-2003) and future projected climate (20752099) datasets from MRI-AGCM3.2H and MRI-AGCM3.2S models were applied with a linear scaling bias correction method before input into the RRI model. The results of climate change suggested that flood magnitude in the LMB will be severer than the present climate by the end of the twenty-first century. The increment of precipitation between 6.6 and 14.2\% could lead to increase extreme flow $\left(\mathrm{Q}_{5}\right)$ 13-30\%, peak inundation area 19-43\%, and peak inundation volume $24-55 \%$ in the LMB for ranging of Representative Concentration Pathways (RCP) and sea surface temperature (SST) scenarios while there is no significant change on peak flood timing.
\end{abstract}

Keywords: Climate change, River discharge, Flood inundation, Lower Mekong Basin

\section{Introduction}

The impacts of climate change became one among the global concerns threatening the environments and natural resources. The Intergovernmental Panel on Climate Change (IPCC) AR5 reported the increase of global average temperature from $1.0^{\circ} \mathrm{C}$ in the lowest emission scenario to $3.7^{\circ} \mathrm{C}$ in the highest emission scenario by 2100 (IPCC 2014). Climate change has an impact on the hydrological system by altering the hydrological cycle and precipitation patterns (Wang et al. 2013). The spatial and temporal patterns of precipitation are the main factors affecting flow regimes and climate conditions (Beyene et al. 2010; Wu et al. 2016). The variation

\footnotetext{
* Correspondence: trysophal001@gmail.com

'Graduate School of Engineering, Kyoto University, Gokasho, Uji 611-0011, Japan

${ }^{4}$ Faculty of Hydrology and Water Resource Engineering, Institute of Technology of Cambodia, Russian Conf. Blvd, Phnom Penh 12156, Cambodia Full list of author information is available at the end of the article
}

of precipitation patterns would disturb the water system in the entire catchment. In Southeast Asia, the precipitation was projected to increase from 1 to $8 \%$ at the end of the twenty-first century (Oeurng et al. 2019). The future hydrologic system will be severely affected by climate change in the Mekong Rivere Basin (MRB) (Lauri et al. 2012; Perera et al. 2017) and its sub-basins: the Tonle Sap Lake (Oeurng et al. 2019) and the Sekong, Sesan, and Srepok Rivers (Oeurng et al. 2016; Shrestha et al. 2016). The increment of river discharge is expected during flood season, while the severe droughts are plausible to happen in the dry season (Oeurng et al. 2019). The seasonal inundation and water interchange between the Mekong River and Tonle Sap Lake of Cambodia produce high productive biodiversity, agriculture, and fisheries (Arias et al. 2013; Uk et al. 2018). The Mekong River supports about 70 million people from four countries (Cambodia, Laos PDR, Thailand, and Vietnam) in 
the Lower Mekong Basin (LMB) where most of the areas are prone to flooding (Try et al. 2019). The ecosystem of the lake and its floodplain are prone to be affected by altering the hydrological cycle in the Mekong River (Arias et al. 2012).

It is a challenge to predict the change of flow regime (Bates et al. 2008). The IPCC AR5 published climate change scenarios known as the Representative Concentration Pathways (RCP) (IPCC 2014). The RCP scenarios incorporate four emission scenarios of greenhouse gas: a stringent mitigation scenario (RCP2.6), two intermediate scenarios (RCP4.5 and RCP6.0) and one very high GHG emission scenario (RCP8.5). The future projections given by IPCC reports were based on general circulation models (GCMs) outputs. GCMs are generally capable to produce a coarse resolution that might consist of large uncertainty. Generally, downscaling approaches were taken: statistical downscaling and dynamical downscaling to produce the regional climate condition. The uncertainties of GCMs were dominantly caused by coarse resolution (Li et al. 2012). To overcome this uncertainty, this study used the outputs from two high-resolution atmospheric general circulation models (AGCMs), namely as MRI-AGCM3.2S and MRI-AGCM3.2H with $20 \mathrm{~km}$ and $60 \mathrm{~km}$ spatial resolution respectively. The model performed a historical climate experiment using observed sea surface temperature, and they showed the improvement in heavy monthly mean precipitation around the tropical pacific region confirmed by numerical skill score (Mizuta et al. 2012).

A hydrological model is an effective tool that can simulate hydrological characteristics under different scenarios. Various hydrological models were developed and applied to investigate the hydrological processes in the MRB and its tributaries: Soil and Water Assessment Tool (SWAT) model (Arnold et al. 1998), Vmod model (Koponen et al. 2010), 2-D Local Inertial Equation (2-D LIE) model (Tanaka et al. 2018), and Rainfall-RunoffInundation (RRI) model (Sayama et al. 2015). Try et al. (2020) used the RRI model for comparison of gridded precipitation products for flood inundation modeling in the MRB. Perera et al. (2017) applied the same model to assess the climate change impacts on hydrological analysis in the MRB using outputs from atmospheric general circulation models (AGCM) based on RCP8.5 scenario considering different sea surface temperature (SST) boundary condition; however, their study did not consider different emission of greenhouse gas scenarios.

To further understand hydrological study of climate change impacts in the MRB, this study aims to predict the changes of extreme river discharge in the MRB and aspects of extreme flood inundation such as inundation area, inundation volume, peak inundation duration and time, and inundation probability in the LMB by using present climate (1979-2003) and future projected climate (2075-2099) from high and super high-resolution AGCM models.

\section{Materials and methods \\ Study area}

The MRB is the largest river in Southeast Asia traveling across China, Myanmar, Laos PDR, Thailand, Cambodia, and Vietnam (Fig. 1). Annual flooding is an important hydrological characteristic of the MRB where it drives the high productivity of ecosystems and biodiversity (Lamberts and Koponen, 2008), particularly the Tonle Sap floodplain and the Mekong Delta (Kummu et al. 2006). The total basin area of the MRB is $795,000 \mathrm{~km}^{2}$, and its average discharge is $14,500 \mathrm{~m}^{3} / \mathrm{s}$ (MRC 2005). The MRB is located in the tropical monsoon climate with two seasons: rainy season (May-October) and dry season (November-April) (MRC 2005). The flood season, accounting $80-90 \%$ of annual flow, is exclusively important for maintaining the aquatic ecosystem in the basin (MRC 2010). The Tonle Sap Lake in the LMB has a unique hydrologic system of two-directional flows. In the dry season, the water flows from the Tonle Sap Lake to the Mekong River, while the water level of the river is higher than the water level in the lake causing the water flowing backward to the Tonle Sap Lake in the rainy season. The surface area of the lake expands from 2600 $\mathrm{km}^{2}$ in the dry season to $12,000 \mathrm{~km}^{2}$ in the wet season resulting in the inundation from the floodplain (Oeurng et al. 2019).

\section{Climate change datasets}

The Meteorological Research Institute (MRI) developed a high-resolution (MRI-AGCM3.2H, $60 \mathrm{~km}$ ) (Mizuta et al. 2012) and a super high-resolution atmospheric climate models (MRI-AGCM3.2S, $20 \mathrm{~km}$ ) (Kitoh and Endo, 2016; Mizuta et al. 2014) with hourly temporal scale. The climate parameters (precipitation and evapotranspiration) were used as input for the RRI model for two 25-year periods: present climate covering of 19792003 and the future climate (2075-2099). The MRIAGCM3.2H model was projected from present (HPA $\mathrm{m} 01$ ) to future climate based on degree of GHG emission ranking from low emission (RCP2.6) to high emission (RCP8.5), namely as HFA_rcp26, HFA_rcp45, HFA_rcp60, and HFA_rcp85, respectively. The MRIAGCM3.2S model was simulated for the present climate (1979-2003) using observed boundary condition of SST (SPA_m01). The different SST patterns for future projection under RCP8.5 scenario were characterized by using SST as output from 28 GCMs in Coupled Model Inter-comparison Project Phase 5 (CMIP5) (Taylor et al. 2012). The future climate experiments (2075-2099) were grouped with SST distributions into four clusters: 8- 


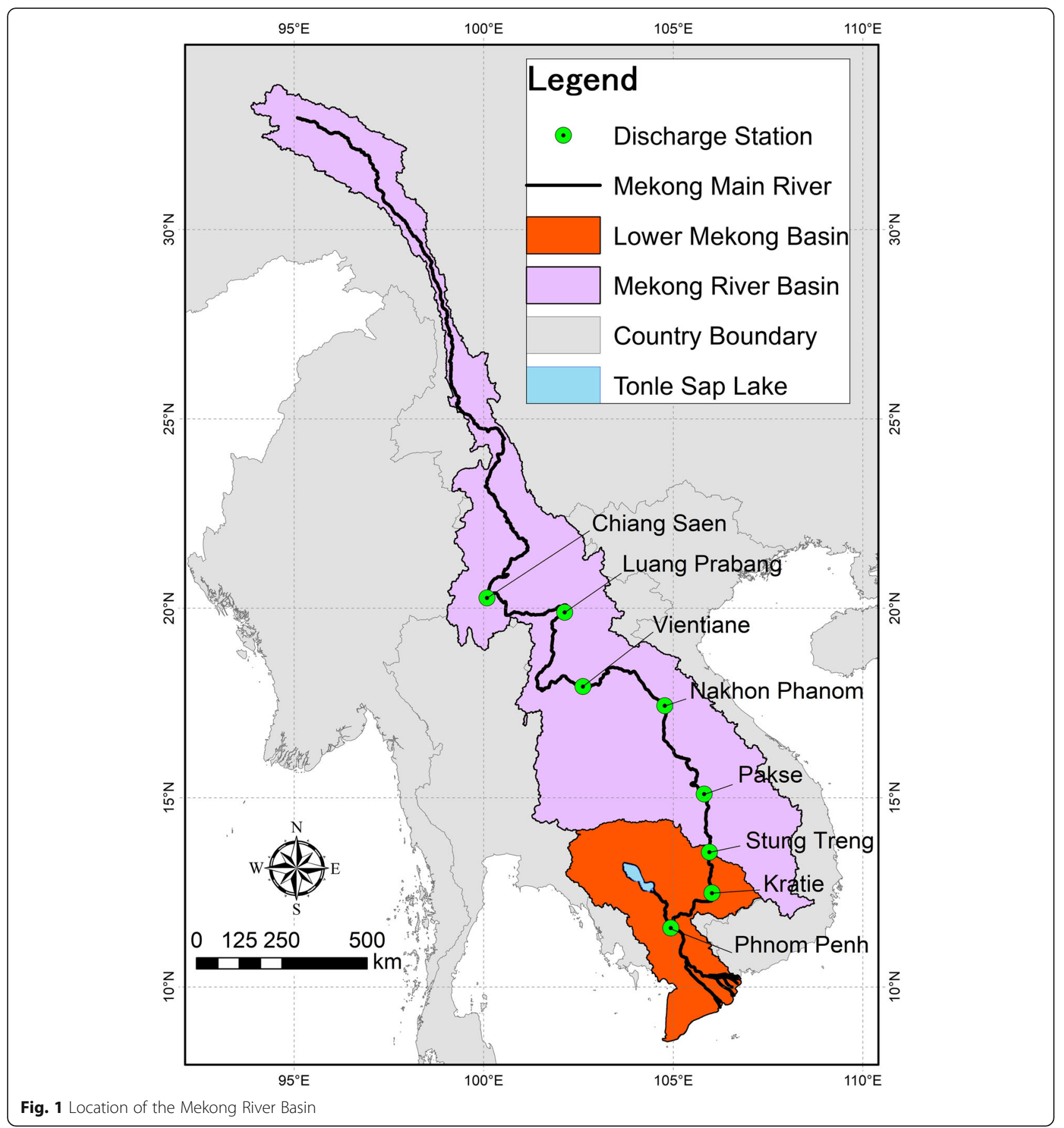

model average (uniform warming in the northern and southern hemispheres), 14-model average (El Ninolike pattern with a larger warming belt in the central equatorial Pacific), 6-model average (a larger warming in the northern hemisphere than in the southern hemisphere), and total 28-model average labeled as SFA_rcp85_c1, SFA_rcp85_c2, SFA_rcp85_c3, and SFA_rcp85, respectively. GPCC was determined to be an accurate precipitation product in the MRB region (Try et al. 2020). Therefore, this precipitation was used as a reference for bias correction as the following linear scaling method:

$$
\mathrm{P}_{\mathrm{hr}}^{\mathrm{BC}}=\frac{\mathrm{P}_{\mathrm{mon}}^{\mathrm{obs}}}{\mathrm{P}_{\mathrm{mon}}^{\mathrm{agcm}}} \times \mathrm{P}_{\mathrm{hr}}^{\mathrm{agcm}}
$$

where $\mathrm{P}_{\text {mon }}^{\mathrm{obs}}$ : average monthly GPCC precipitation, $\mathrm{P}_{\text {mon }}^{\mathrm{agcm}}$ : average monthly AGCM precipitation, $\mathrm{P}_{\mathrm{hr}}^{\mathrm{agcm}}$ : hourly AGCM precipitation, and $\mathrm{P}_{\mathrm{hr}}^{\mathrm{BC}}$ : hourly bias-corrected 
AGCM precipitation. The correction factor calculated from the present climate was applied to future climate experiments.

The different climate change scenarios would lead to generate different evapotranspiration (ET) in the future. For example, when precipitation increases in the future, and ET may also increase due to the increase of temperature increase. In this case, the surface runoff might not change following only precipitation change. In order to eliminate this uncertainty for future projection, the correction of future ET was calculated by extracting ET from present and future climates of AGCMs as the following equation.

$$
\mathrm{ET}_{\text {fut }}=\mathrm{ET}_{\text {JRA }-55}+\Delta \mathrm{ET}_{\text {fut }}
$$

where $\mathrm{ET}_{\text {fut }}$ is $\mathrm{ET}$ for each future scenario; $\mathrm{ET}_{\text {JRA }-55}$ is evapotranspiration from JRA-55 dataset; and $\Delta \mathrm{ET}_{\text {fut }}$ is the change of ET for each future scenario comparing to their present climates.

\section{RRI model simulation}

The rainfall-runoff-inundation (RRI) model was used to simulate runoff and flood inundation for the MRB. The RRI model is a two-dimensional distributed hydrodynamic model that is able to simulate rainfall-runoff and inundation processes simultaneously (Sayama et al. 2012, 2015). The slope grid cells receive rainfall and flow based on 2D diffusive wave equations, while the inchannel flow is calculated with 1D diffusive equations. Topographic information (digital elevation model (DEM), flow direction, and flow accumulation), obtained from the Multi-Error-Removed-Improved-Terrain (MERIT DEM, Yamazaki et al. 2017), were used as input to the RRI model. The river geometry was available from the Mekong River Commission, and land use was from MODIS (product: MCD12Q1) for 2000 (Friedl et al. 2010). The simulation setting was separated into two parts. First, the model was set up with $2.5^{\prime}$ resolution (approx. $5 \mathrm{~km}$ ) for the whole MRB for assessing river discharge. Then, the model was set up with 1.5' resolution (approx. $2.7 \mathrm{~km}$ ) for the LMB for predicting more accurate flood inundation. Try et al. (2020) evaluated the performance of five various gridded precipitation datasets for rainfall-runoff and inundation modeling over the MRB. The result showed that the Global Precipitation Climatology Centre (GPCC) product was suitable for long-term hydrological modeling in the MRB comparing to other precipitation products: APHRODITE, TRMM-3B42V7, PERSIANN-CDR, and GSMaP. Based on retrospective experiment, this study conducted a simulation of 25 years (1982-2007) using GPCC precipitation for model verification. The surface evapotranspiration was available from the Japanese 55-year Reanalysis dataset (JRA-55) with 3-hourly and $0.5625^{\circ}$ resolution (Kobayashi et al. 2015). The calibrated RRI model and its parameter setting (Table 1) were retrieved from Try et al. (2020). The performance of river discharge and flood inundation was compared between the observation and simulation results. After verification of the hydrodynamic model, the same parameter setting was used to simulate river discharge and flood inundation using the climate change dataset.

To evaluate the performance of the model, we used indicators as the following: Nash-Sutcliffe model efficiency (NSE), coefficient of determination $\left(R^{2}\right)$, and root mean square error (RMSE):

$$
\begin{aligned}
& \mathrm{NSE}=1-\frac{\sum\left(Q_{\text {sim }}(t)-Q_{\mathrm{obs}}(t)\right)^{2}}{\sum\left(Q_{\mathrm{obs}}(t)-\overline{Q_{\mathrm{obs}}}\right)^{2}} \\
& \mathrm{R}^{2}=\frac{\sum\left(\left(Q_{\mathrm{sim}}(t)-\overline{Q_{\text {sim }}}\right)\left(Q_{\mathrm{obs}}(t)-\overline{Q_{\mathrm{obs}}}\right)\right)^{2}}{\sum\left(Q_{\mathrm{sim}}(t)-\overline{Q_{\text {sim }}}\right)^{2} \sum\left(Q_{\mathrm{obs}}(t)-\overline{Q_{\mathrm{obs}}}\right)^{2}} \\
& \mathrm{RMSE}=\sqrt{\frac{\sum\left(Q_{\text {sim }}(t)-Q_{\mathrm{obs}}(t)\right)^{2}}{n}}
\end{aligned}
$$

where $Q_{\text {sim }}(t)$ and $Q_{\text {obs }}(t)$ are the simulated and observed discharge at time step $t . \overline{Q_{\text {sim }}}$ and $\overline{Q_{\text {obs }}}$ are the simulated

\begin{tabular}{|c|c|c|c|c|}
\hline Parameters & & & Mountains & Plains \\
\hline Manning's coefficient for slope & $n$ & $\left(m^{-1 / 3} s\right)$ & 0.4 & 0.015 \\
\hline Soil depth & $d$ & $(\mathrm{~m})$ & 2.0 & - \\
\hline Lateral saturated hydraulic conductivity & $k_{\mathrm{a}}$ & $(\mathrm{m} / \mathrm{s})$ & 0.1 & - \\
\hline Parameter of unsaturated hydraulic conductivity & $\beta$ & - & 9.0 & - \\
\hline Vertical hydraulic conductivity & $k_{\mathrm{v}}$ & $(\mathrm{cm} / \mathrm{h})$ & - & 0.06 \\
\hline Soil porosity & $\varphi$ & - & - & 0.6 \\
\hline Wetting front soil suction head & $S_{f}$ & - & - & 0.273 \\
\hline Manning's coefficient for river & $n_{\text {river }}$ & $\left(m^{-1 / 3} s\right)$ & 0.03 & \\
\hline
\end{tabular}
and observed average discharge, and $n$ is the number of data.

Table 1 The values of parameter setting of the RRI model used in the study 
To evaluate the performance of flood extent, two of the following indices including true ratio (TR) and hit ratio $(\mathrm{HR})$ were used:

$$
\begin{aligned}
& \mathrm{TR}=\frac{\mathrm{IC}_{\mathrm{obs}} \cap \mathrm{IC} \mathrm{C}_{\text {sim }}}{\mathrm{IC}_{\text {sim }}} \\
& \mathrm{HR}=\frac{\mathrm{IC}_{\text {obs }} \cap \mathrm{IC}_{\text {sim }}}{\mathrm{IA}_{\mathrm{obs}}}
\end{aligned}
$$

where $\mathrm{IC}_{\text {sim }}$ and $\mathrm{IC}_{\mathrm{obs}}$ are the number of inundated cell from simulation and observation. The observed inundation maps were available from NASA MODIS near real-time global flood mapping product (https://floodmap.modaps.eosdis.nasa.gov/) whose spatial and temporal resolutions are $250 \mathrm{~m}$ and 3 days for global scale (Nigro et al. 2014).

\section{Assessing climate change impacts}

In addition to assessing the impacts of climate change on extreme river flow and flood inundation in the MRB, the change of precipitation was also examined. The monthly precipitation of the projected future climate was compared with that of the present climate for the entire MRB. Next, the mean annual flow $\left(Q_{\mathrm{m}}\right)$ and the high flow exceeded $5 \%$ of the time $\left(Q_{5}\right)$ were calculated. Further, the changes of inundation area and volume, flood probability, inundation peak time, and duration were also evaluated from the present period (1979-

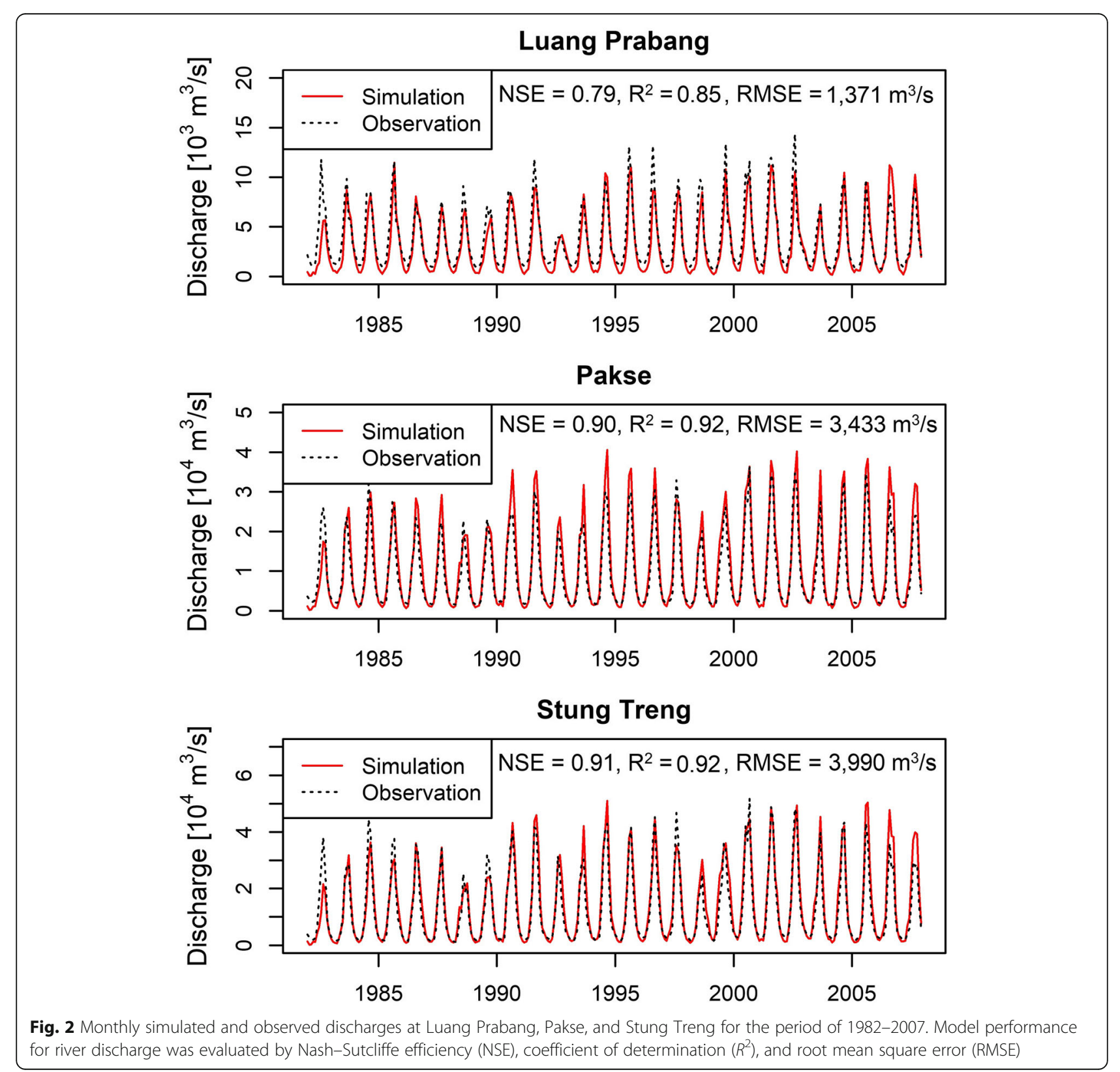


Table 2 The statistical indices of model performance of flood extent true ratio (TR) and hit ratio (HR)

\begin{tabular}{llllllllll}
\hline & 2000 & 2001 & 2002 & 2003 & 2004 & 2005 & 2006 & 2007 & Avg. \\
\hline TR & 0.82 & 0.74 & 0.65 & 0.42 & 0.58 & 0.46 & 0.49 & 0.47 & 0.58 \\
HR & 0.85 & 0.80 & 0.87 & 0.89 & 0.76 & 0.88 & 0.94 & 0.89 & 0.86 \\
\hline
\end{tabular}

2003) to the future period (2075-2099). Moreover, the statistical Kolmogorov-Smirnov (K-S) test, a nonparametric test of two samples, was used to check the variation of flood inundation between present and future climates. The maximum difference of the cumulative distribution function of the two samples is defined by:

$$
D_{n, m}=\sup _{x}\left|F_{n}(x)-F_{m}(x)\right|
$$

where $F_{n}$ and $F_{m}$ are the empirical distribution functions of the two samples, and sup is supremum function. The null hypothesis, $H_{0}$, assumes that two samples have no significant difference in CDF. When the likelihood of the different distribution of the two samples exceeds a significance level, the null hypothesis is rejected. Two samples have different distribution if

$$
D_{n, m}>c(\alpha) \sqrt{\frac{n+m}{n m}}
$$

where $n$ and $m$ are the sample sizes. At the significance level $5 \%$ used in this study, $c(\alpha)$ is equal to 1.36 .

\section{Results}

\section{Performance of the model simulation}

The RRI model simulated for 1982-2007 considering as model verification period, and the performance indices of NSE, $R^{2}$, and RMSE were calculated at three stations along the mainstream of the MRB: Luang Prabang, Pakse, and Stung Treng. These three stations were selected according to the availability of observed discharge, and their locations vary in the upper part of the LMB (i.e., Luang Prang is located near the outlet from the

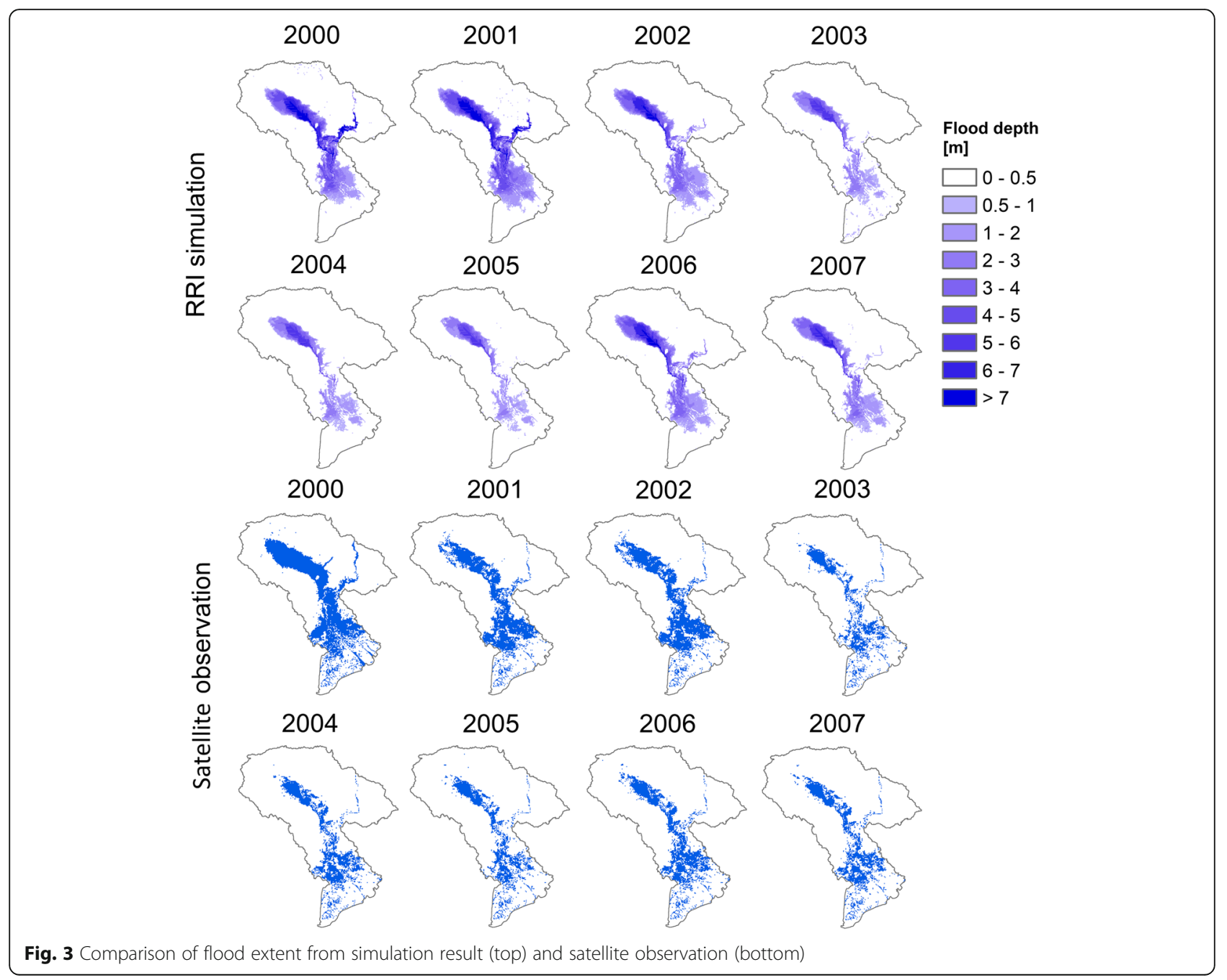


Upper Mekong in China), middle part (Pakse), and downstream of the LMRB (Stung Treng). Figure 2 showed the simulated and observed monthly discharge at the three locations. In general, the hydrographs of observation and simulation had similar pattern of all three stations; however, the model predicted underestimation in the low flow season in Luang Prabang. The evaluation statistics were NSE $=0.79 . R^{2}=0.85$, and $\mathrm{RMSE}=1371$ $\mathrm{m}^{3} / \mathrm{s}$. At Pakse, the performance indices were NSE = $0.90, R^{2}=0.92$, and RMSE $=3433 \mathrm{~m}^{3} / \mathrm{s}$. The prediction at Stung Treng was high performance (NSE $=0.91, R^{2}=$ 0.92); however, large flow at this location produced more error value $\left(\mathrm{RMSE}=3990 \mathrm{~m}^{3} / \mathrm{s}\right.$ ) than other locations.

The performance of annual maximum flood inundation was determined using true ratio (TR) and hit ratio (HR). The observed flood extent was obtained from the NASA MODIS flood observation dataset (Nigro et al. 2014) for the period of 2000-2007. The threshold of inundation depth of $0.5 \mathrm{~m}$ was selected following the previous studies (Sayama et al. 2012 and 2015; Try et al. 2018) to identify the flood and non-flood areas. The statistic indices of observation and model prediction flood extent were listed in Table 2 (see Fig. 3 for the comparison map of simulation and observation). The spatial performance index TR ranged from 0.42 to 0.82 during 2000-2007 where the average accuracy was 58\% (avg. $\mathrm{TR}=0.58$ ). The HR indicator varied from 0.76 to 0.94 , and its mean accuracy was $86 \%$ (avg. $\mathrm{HR}=0.86$ ). The factors which reduced inundation accuracy would come from two main sources. First, the satellite observation would not be able to detect flooded area at the mangrove forests on the banks of the Tonle Sap Lake while the simulation might correctly identify these areas under inundation. Secondly, the simulation was not able to detect inundated area in some low parts of the Mekong delta where might be influenced by saltwater intrusion. This effect was not considered in this study due to unavailability of observed information.

\section{Precipitation changes}

The bias correction performance was checked by comparing the precipitation and simulated discharge of historical AGCMs before and after bias correction. Figure 4 shows average daily precipitation and simulated discharge comparing between GPCC and AGCMs before and after bias correction. The raw precipitation and discharge had seasonal bias (i.e. overestimation) at the beginning of the wet season. The performance of average daily AGCM precipitation before and after bias correction was improved with $R^{2}$ from 0.85 to 0.94 for SPA_m01 and from 0.87 to 0.93 for HPA_m01, respectively. Moreover, the performance discharge was improved from $R^{2}=$ 0.89 and 0.96 to $R^{2}=0.99$ and 0.98 for SPA_m01 and HPA_m01, respectively.

Figure 5 showed the bias-corrected monthly precipitation from MRI-AGCM3.2H and MRI-AGCM3.2S datasets in the present (1979-2003) and future
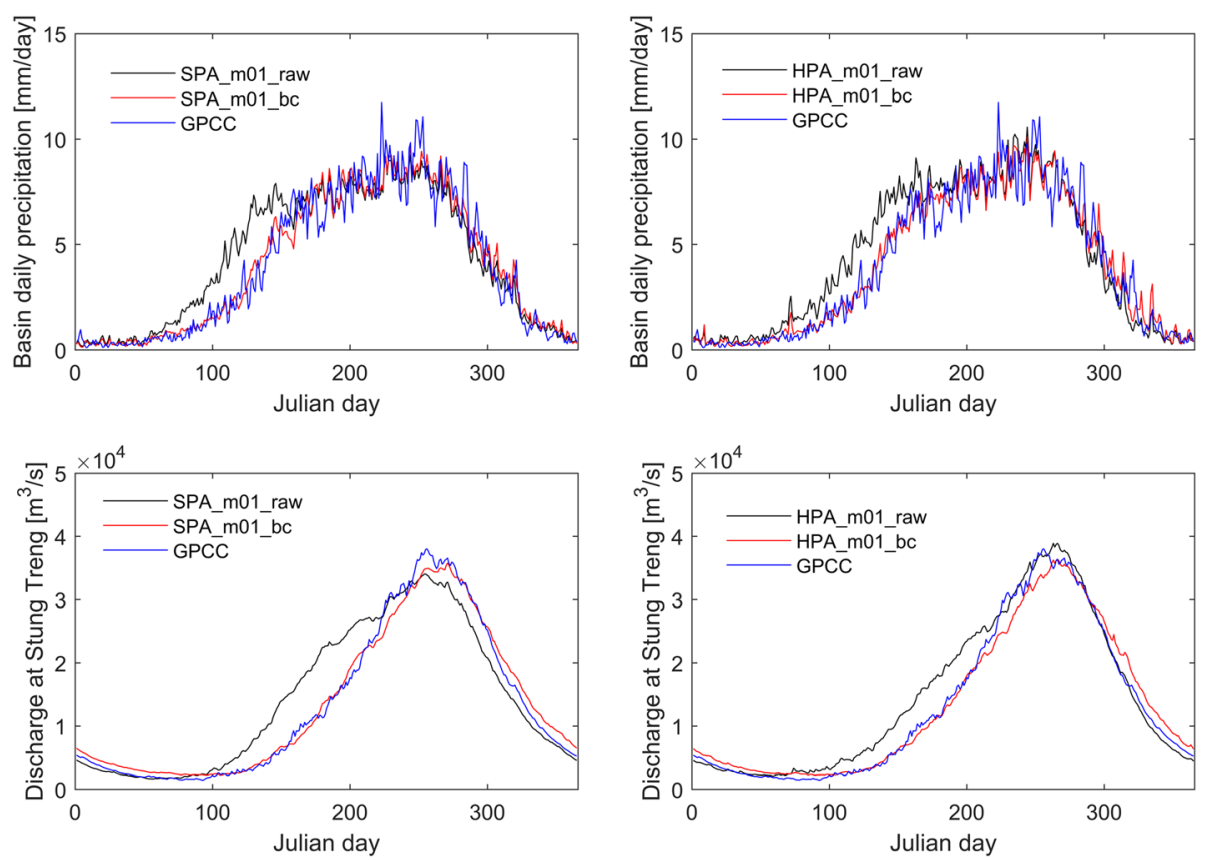

Fig. 4 Comparison of raw and bias corrected average daily precipitation and discharge at Stung Treng for historical AGCMs (SPA_m01 and HPA_m01) with GPCC simulation 


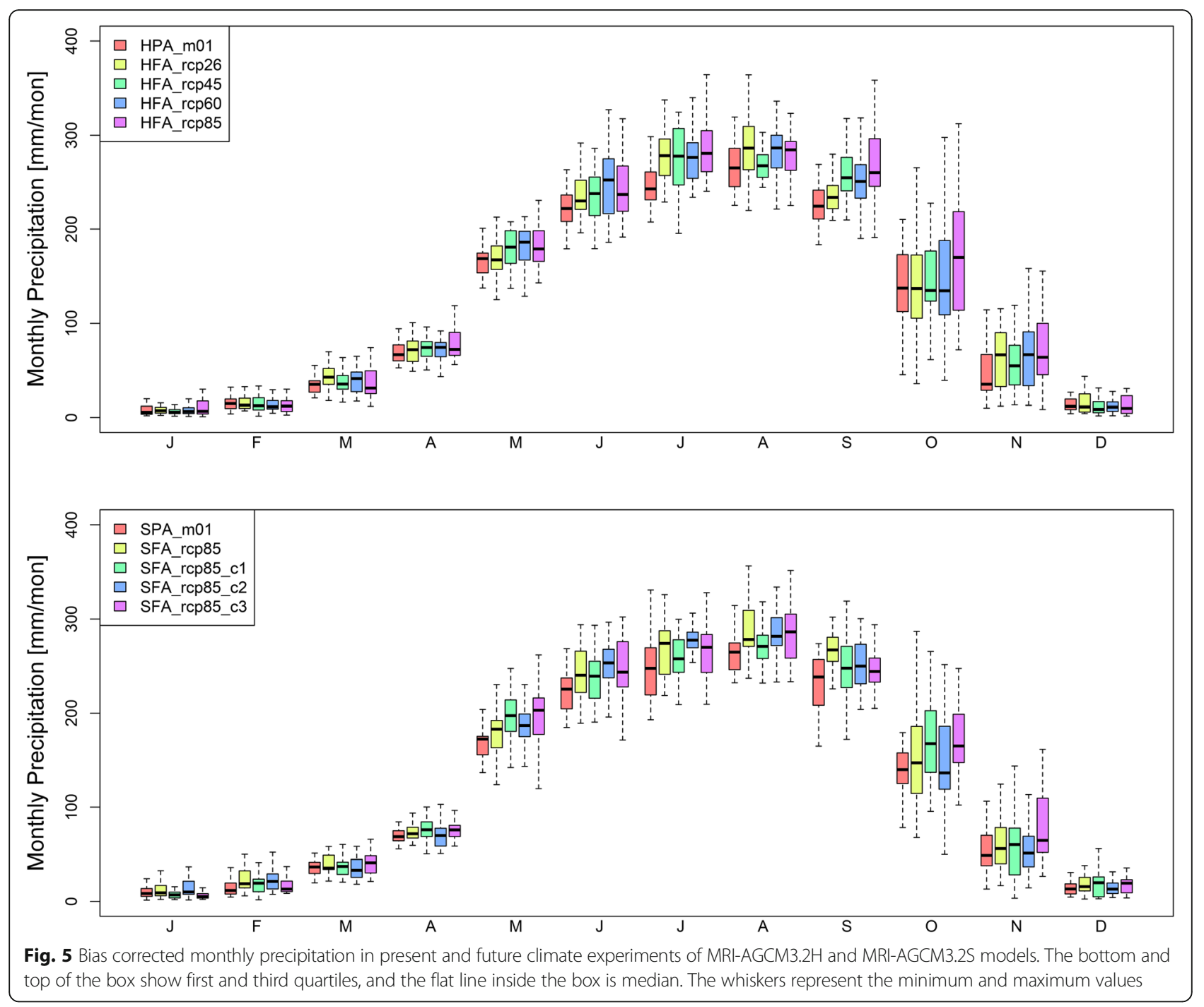

(2075-2099) climates. The basin average precipitation was expected to increase for RCP and SST scenarios during the rainy season (May-October). During the late rainy season in September, the precipitation of future scenarios of HFA_rcp45, HFA_60, and HFA rcp85 significantly raised up while less increase could be observed in HFA_rcp26. Three future SST patterns (SFA_rcp85, SFA_c2, and SFA_c3) provided higher increase of precipitation than SFA_rcp85_c1 in rainy season comparing to their present climate SPA_m01. The annual precipitation would increase by $6.6 \%$, $8.0 \%, 9.5 \%$, and $14.2 \%$ for four RCP scenarios (RCP2.6-RCP8.5), and four SST pattern scenarios had less diversified increasing (9.9-12.5\%).

\section{Effects of climate change on river flow}

The future changes in river discharge were assessed by simulation of RRI model using precipitation and evapotranspiration projected by MRI-AGCM3.2H and MRI-
AGCM3.2S models from present climate (1979-2003) to the future climate (2075-2099) for four greenhouse gas emission scenarios (RCP2.6, RCP4.5, RCP6.0, and RCP8.5) and four SST scenarios (Fig. 6). The flow change was examined at four locations along the mainstream of the MRB. Table 3 showed the mean annual discharge $\left(Q_{\mathrm{m}}\right)$ and extreme river flow exceeding $5 \%$ of the time $\left(Q_{5}\right)$. Overall, $Q_{\mathrm{m}}$ and $Q_{5}$ increased for all future scenarios. The $Q_{\mathrm{m}}$ of the upstream stations (Chiang Saen and Vientiane) was predicted to increase 5-10\% while the downstream stations (Pakse and Kratie) raised up a higher increment of $10-15 \%$ for three climate change scenarios (RCP2.6, RCP4.5, and RCP6.0). The $Q_{\mathrm{m}}$ for all stations significantly escalated for RCP8.5 $(23-26 \%)$ and SST scenarios $(10 \pm 3 \%-29 \pm 3 \%)$. At the end of the twenty-first century, high flow $\left(Q_{5}\right)$ showed increases of $5-14 \%$ at Chiang Saen and Vientiane and $11-18 \%$ at Pakse and Kratie for the three low emission scenarios (RCP2.6, RCP4.5, and RCP6.0). The $Q_{5}$ 

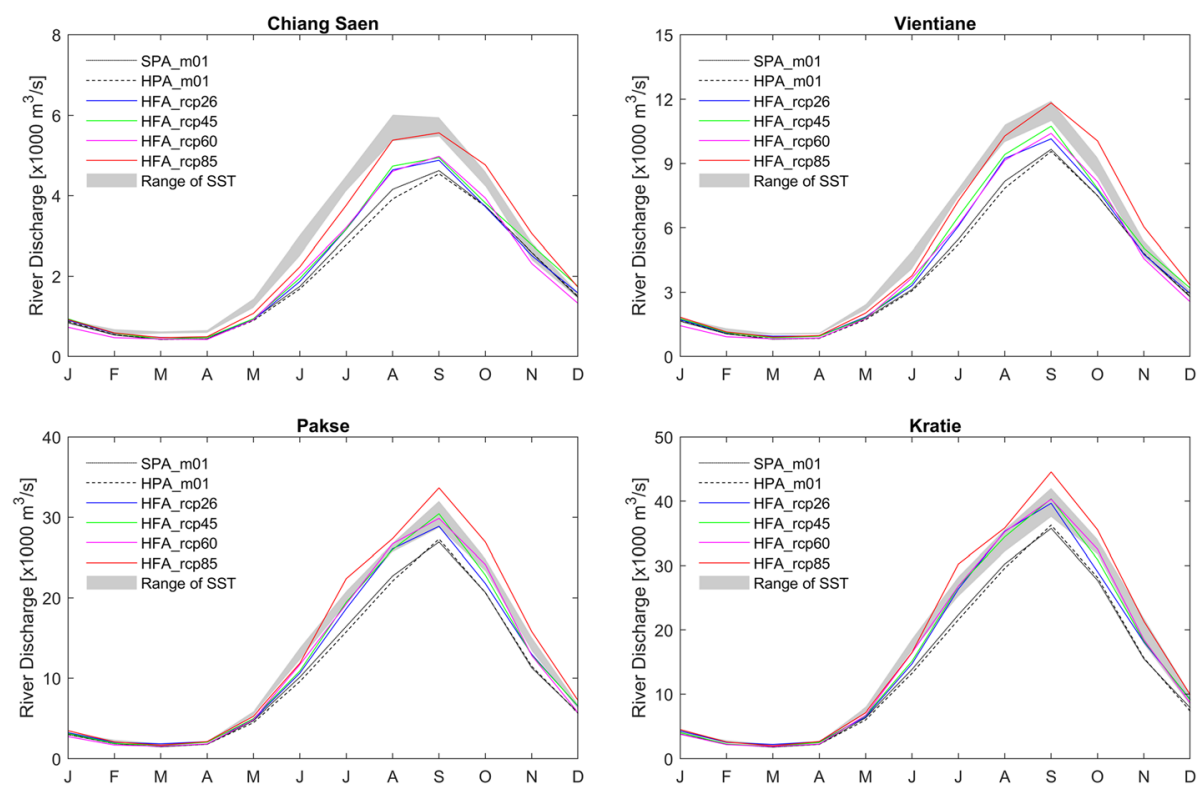

Fig. 6 Average monthly discharge of present and projected future climate experiments of RCP and SST scenarios

Table 3 Changes (\%) of annual mean discharge $\left(Q_{m}\right)$ and flow exceeded $5 \%$ of the time $\left(Q_{5}\right)$ for each RCP and SST scenarios comparing with present climate. The values for SST scenarios show mean $(\mu) \pm$ standard deviation $(\sigma)$

\begin{tabular}{llll}
\hline Station & SCenario & $Q_{m}$ & $Q_{5}$ \\
\hline Chiang Saen & RCP2.6 & $6 \%$ & $9 \%$ \\
& RCP4.5 & $9 \%$ & $10 \%$ \\
RCP6.0 & $5 \%$ & $14 \%$ \\
Vientiane & RCP8.5 & $23 \%$ & $27 \%$ \\
& SST $(\mu \pm \sigma)$ & $10 \% \pm 3 \%$ & $10 \% \pm 4 \%$ \\
& RCP2.6 & $7 \%$ & $5 \%$ \\
PCP4.5 & $10 \%$ & $8 \%$ \\
& RCP6.0 & $7 \%$ & $10 \%$ \\
& RCP8.5 & $23 \%$ & $21 \%$ \\
& SST $(\mu \pm \sigma)$ & $11 \% \pm 2 \%$ & $10 \% \pm 4 \%$ \\
& RCP2.6 & $10 \%$ & $11 \%$ \\
Kratie & RCP4.5 & $13 \%$ & $11 \%$ \\
& RCP6.0 & $13 \%$ & $17 \%$ \\
& RCP8.5 & $26 \%$ & $29 \%$ \\
& SST $(\mu \pm \sigma)$ & $25 \% \pm 3 \%$ & $16 \% \pm 4 \%$ \\
& RCP2.6 & $12 \%$ & $14 \%$ \\
& RCP4.5 & $13 \%$ & $13 \%$ \\
& RCP6.0 & $15 \%$ & $18 \%$ \\
& RCP8.5 & $25 \%$ & $30 \%$ \\
& SST $(\mu \pm \sigma)$ & $29 \% \pm 3 \%$ & $18 \% \pm 3 \%$ \\
\hline
\end{tabular}

momentously stepped up to $21-30 \%$ for four observations stations for RCP8.5 while it ranged between $10 \pm$ $4 \%$ and $18 \pm 3 \%$ for the SST scenario. The peak discharge took place in September (Fig. 6), and this remained the same for all future scenarios at Vientiane, Pakse, and Kratie except Chiang Saen where the peak discharge from SST somehow happened earlier in August.

\section{Effect of climate change on flood inundation}

The flood plain and agricultural land are the majority in the LMB, so the threshold was selected at $0.5 \mathrm{~m}$ of water depth to classify the inundated and non-inundated area. According to the simulation results, flood magnitudes were expected to increase for all future scenarios. Figure 7 showed the 25-year average inundation extent in the present and future climatic conditions. The ratios of mean and variance of the inundation extent of the future and present were 1.19-1.43 and 2.08-3.92 for MRI-AGCM3.2H and 1.26-1.32 and 1.12-2.13 for MRI-AGCM3.2S (Table 4), respectively. Figure 8 showed boxplot comparison of peak inundation time (days of the year (DOY)) and inundation volume in the LMB. There was no significant change of peak flood time of future climate compared to the present climate (i.e., the variation of the median was within \pm 5 days). The K-S test showed result of no significant difference for all future scenarios (RCP and SST) at significant level $5 \%$ ( $p$ value $=0.2370-0.8774)$. The peak inundation volume took place in October for the present climate and all projected future scenarios. However, there was a huge variability in peak inundation volume. The first 

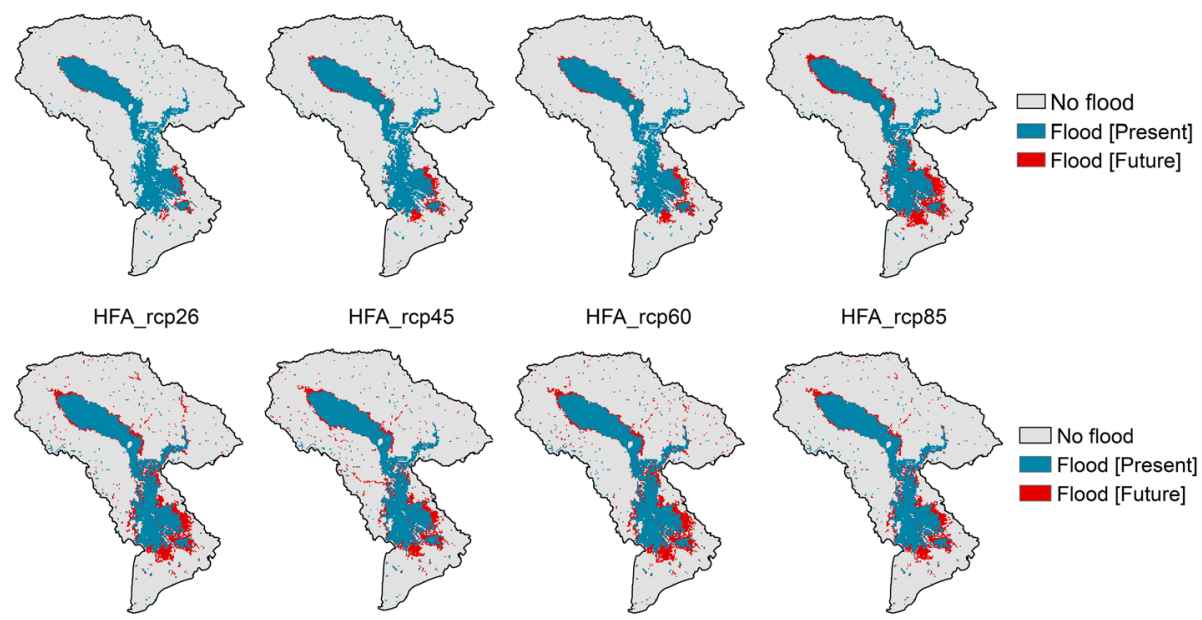

SFA_rcp85

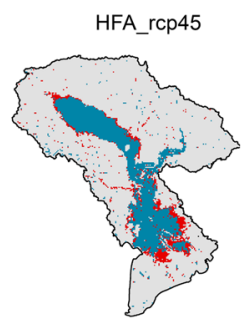

SFA_rcp85_c1

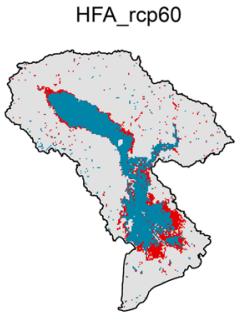

SFA_rcp85_c2

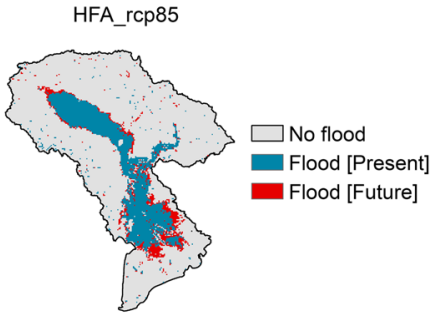

SFA_rcp85_c3

Fig. 7 25-year average of annual maximum inundation extent for the present and the future climate experiments

quartile values of the LMB peak inundation volume (the boxplot in the lower row of Fig. 8) for all future scenarios (100-124 $\mathrm{km}^{3}$ for HFA and $99-118 \mathrm{~km}^{3}$ for SFA) were greater than the third quartile value of their present climates $\left(99 \mathrm{~km}^{3}\right.$ and $98 \mathrm{~km}^{3}$ for HPA and SPA). Median of peak inundation volume for HFA increased between 15\% for RCP2.6 and $42 \%$ for RCP 8.5 and $28-41 \%$ for SST. The relative ratio of the mean of inundation volume varied between 1.24-1.55 and 1.29-1.41, and the relative ratio of inundation volume variance changed $2.30-4.60$ and 1.662.09 (Table 3) for RCP and SST scenarios, respectively. The result of K-S test of peak inundation volume revealed significant difference for all RCP and SST scenarios (i.e., null hypothesis was rejected at significant level of $5 \%$ with $p$ value less than 0.002 ).

Figures 9 and 10 showed the flood inundation probability, the difference of probability of flood inundation

Table 4 The ratio $(F)$ of mean $(\mu)$ and variance $\left(\sigma^{2}\right)$ of inundation area and volume for future climates comparing their present climate

\begin{tabular}{|c|c|c|c|c|c|}
\hline \multirow[t]{2}{*}{ Model } & \multirow[t]{2}{*}{ Scenario } & \multicolumn{2}{|c|}{ Inundation area } & \multicolumn{2}{|c|}{ Inundation volume } \\
\hline & & $\overline{F(\mu)}$ & $F\left(\sigma^{2}\right)$ & $\overline{F(\mu)}$ & $F\left(\sigma^{2}\right)$ \\
\hline \multirow[t]{5}{*}{ MRI-AGCM3.2H } & HFA_rcp26 & 1.19 & 2.28 & 1.24 & 2.68 \\
\hline & HFA_rcp45 & 1.26 & 2.08 & 1.32 & 2.30 \\
\hline & HFA_rcp60 & 1.32 & 3.92 & 1.41 & 4.60 \\
\hline & HFA_rcp85 & 1.43 & 3.37 & 1.55 & 3.96 \\
\hline & Avg. & 1.30 & 2.91 & 1.38 & 3.38 \\
\hline \multirow[t]{5}{*}{ MRI-AGCM3.2S } & SFA_rcp85 & 1.32 & 1.12 & 1.41 & 1.66 \\
\hline & SFA_rcp85_c1 & 1.26 & 2.13 & 1.29 & 1.98 \\
\hline & SFA_rcp85_c2 & 1.32 & 1.67 & 1.38 & 2.09 \\
\hline & SFA_rcp85_c3 & 1.27 & 2.08 & 1.30 & 1.89 \\
\hline & Avg. & 1.29 & 1.75 & 1.34 & 1.90 \\
\hline
\end{tabular}

from the present to future (dP), and the K-S test result for each climate model. The $\mathrm{dP}$ clearly indicated the positive value for all projected future scenarios. For MRIAGCM3.2H, the $\mathrm{dP}$ ranged from one less increasing (HFA_rcp26), two medium increase (HFA_rcp45 and HFA_rcp60), and one large increase (HFA_rcp85). Among the area of significant difference of inundation probability $(\mathrm{dP} \geq 0.05$ in Figs 9 and 10), the proportion for area $\mathrm{dP} \geq$ 0.3 was just only $12 \%$ (i.e., area of proportion $0.05 \leq \mathrm{dP}<$ 0.03 was $88 \%$ ) for RCP2.6, and this proportion raised up to $48 \%, 40 \%$, and $56 \%$ for HFA_rcp 45 , HFA_rcp60, and HFA_rcp85, respectively. On the other hand, the same proportion value of $\mathrm{dP} \geq 0.3$ had less diversification (i.e., 54-62\%) for ranges of SST scenarios. The spatial K-S test indicated almost not significant in HFA_rcp26 and partial significant in HFA_rcp45 and HFA_rcp60 while large area was found significant in HFA_rcp85. The K-S test for SST patterns determined significant at most area in SFA_rcp85 following by SFA_rcp85_c3, and SFA_rcp85_c2 and SFA rcp85_c1 had less area of significant.

The inundation duration, change of duration, and its spatial K-S test results were illustrated in Figs. 11 and 12 for MRI-AGCM3.2H and MRI-AGCM3.2S, respectively. The variation of inundation duration per 25-year in the present and future between -1 and 1 day was considered as no change in this study. Overall, the longer durations of inundation were observed for the LMB for both RCP and SST scenarios. The area with high flood inundation probability commonly experienced long flood durations while the low probability place corresponded with a shorter duration of inundation. Similarly, the spatial K-S test showed significant at most of area regardless of RCP and SST scenarios. The increasing of flood duration was observed at the floodplain except inside the Tonle Sap Lake where the water exists for the whole year. 

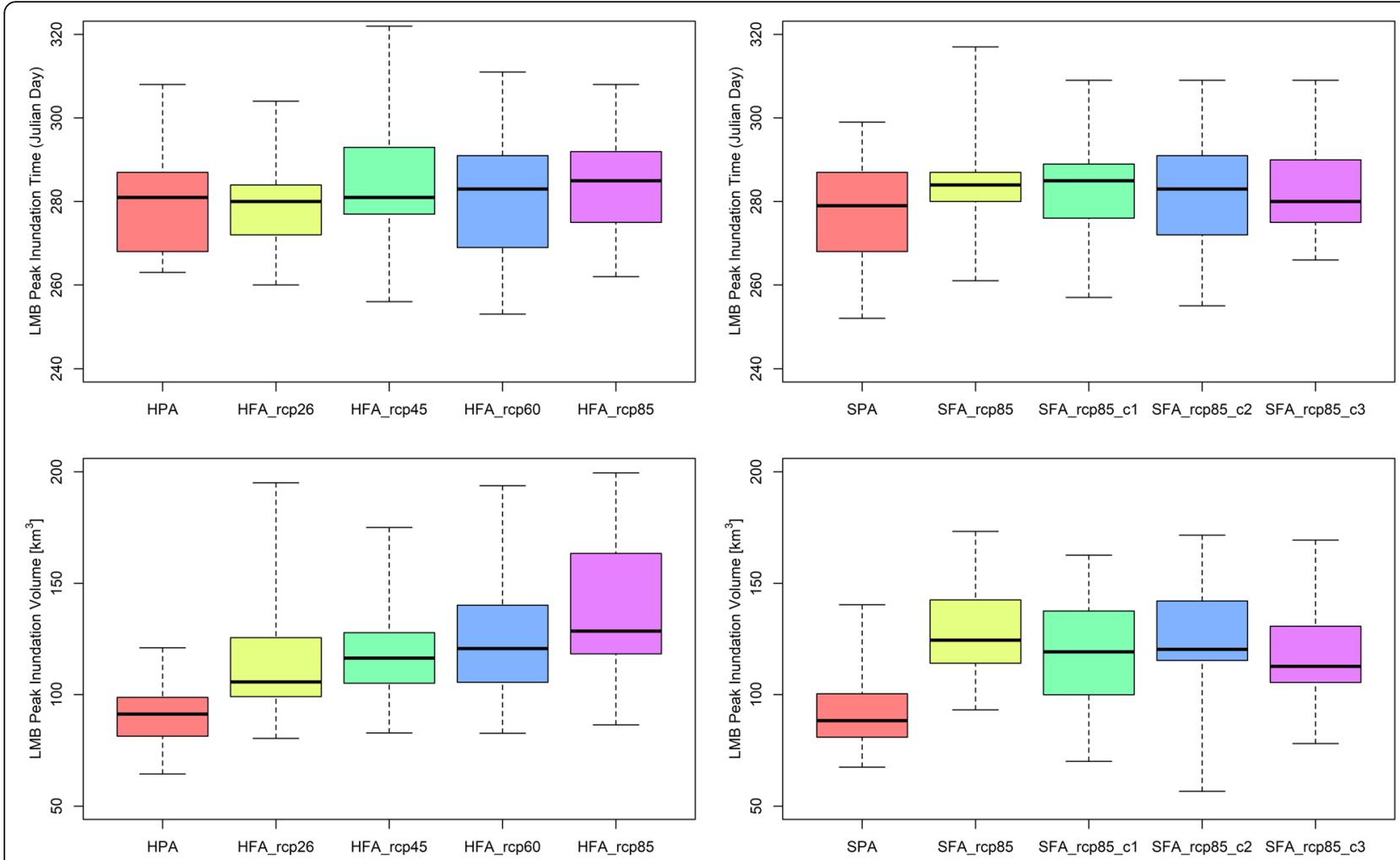

Fig. 8 Peak inundation time (upper row) and peak inundation volume (lower row) in the LMB resulted from MRI-AGCM3.2H model (left column) and MRI-AGCM3.2S model (right column). The boxplot explanation is the same as Fig. 5

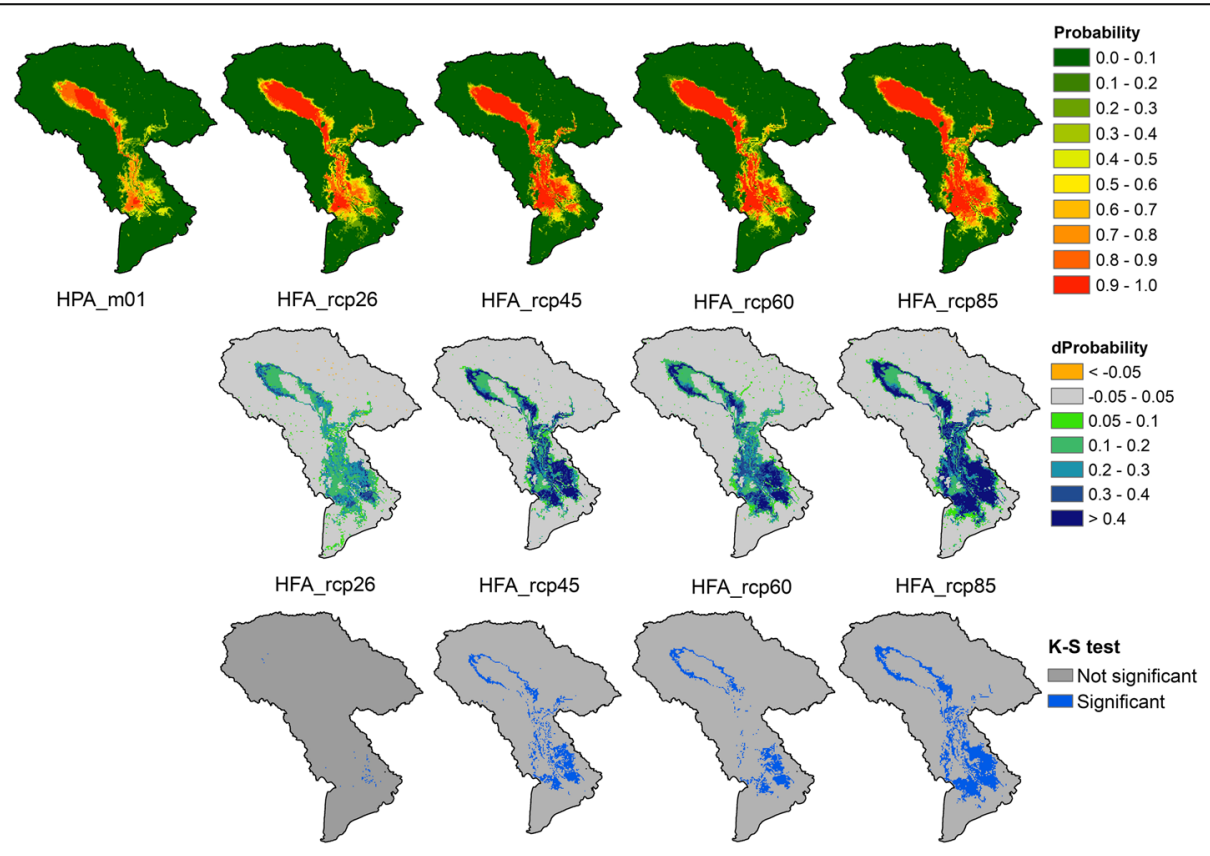

Fig. 9 Spatial distribution of inundation probability (upper row), difference between present and each future RCP scenarios (middle row), and K-S test (lower row) for MRI-AGCM3.2H model 


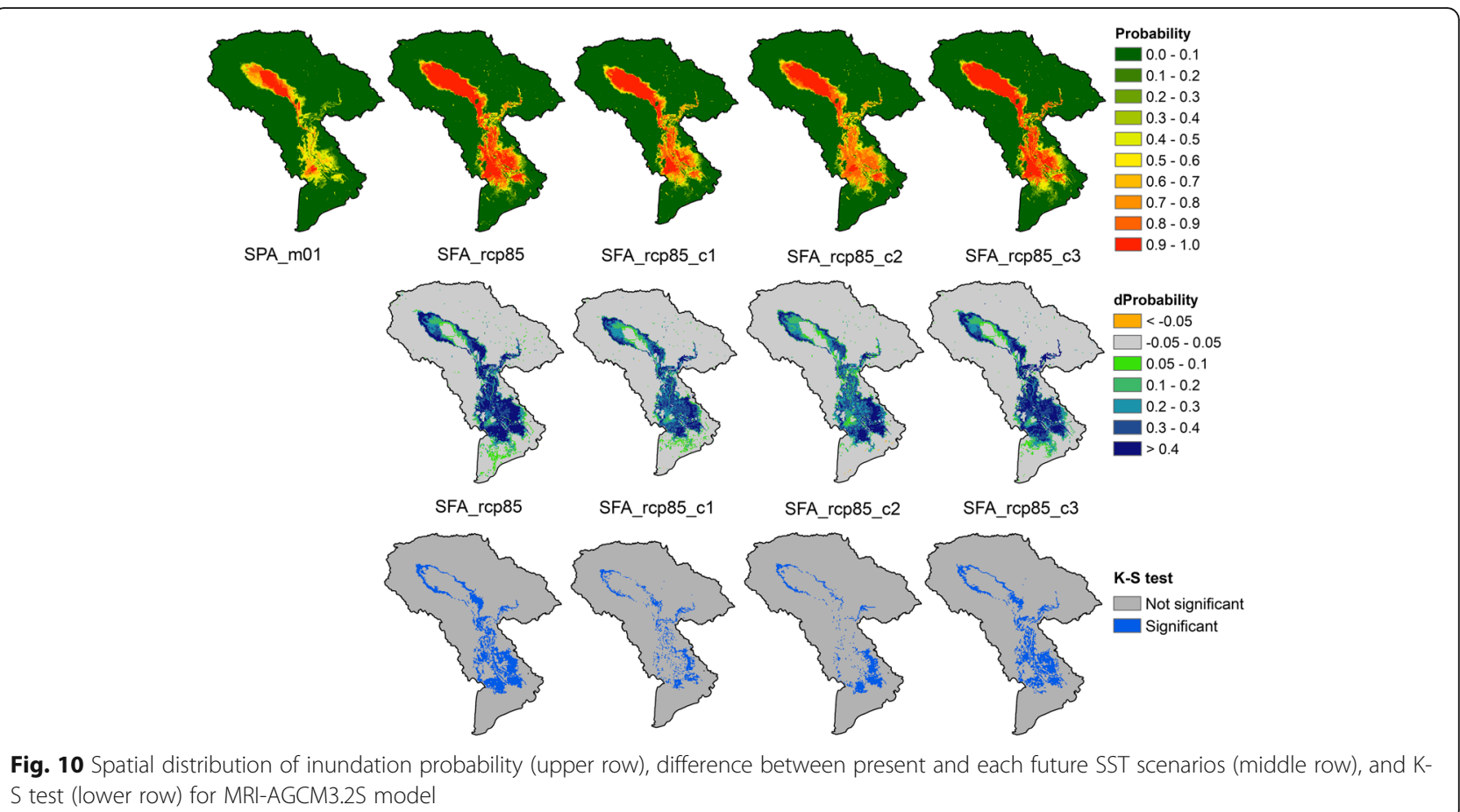

\section{Discussion}

\section{Benefits of high-resolution data}

This study used two high-resolution models MRIAGCM3.2H and MRI-AGCM3.2S with spatial resolution of $60 \mathrm{~km}$ and $20 \mathrm{~km}$. To see benefits of fine spatial-scale, two other coarse-resolution GCMs (MRI-CGCM3 and
MRI-ESM1) from the CMIP5 were examined to compare their performance without bias correction for 25year in the historical climate (1979-2003). The grid resolutions of MRI-CGCM3 and MRI-ESM1 are $125 \mathrm{~km} \times$ $125 \mathrm{~km}$. Figure 13 showed the comparison of spatial distribution of annual average precipitation of GPCC and

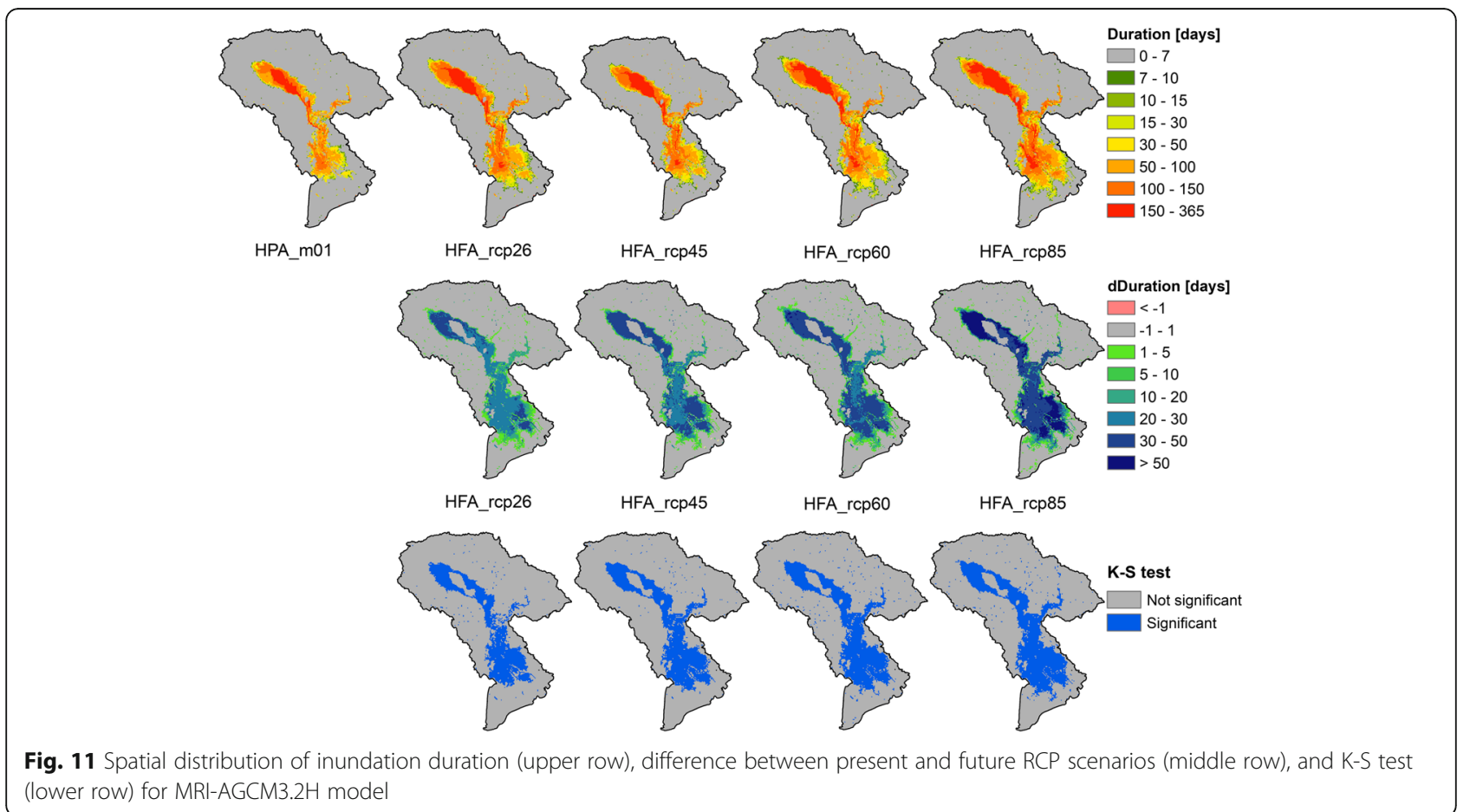



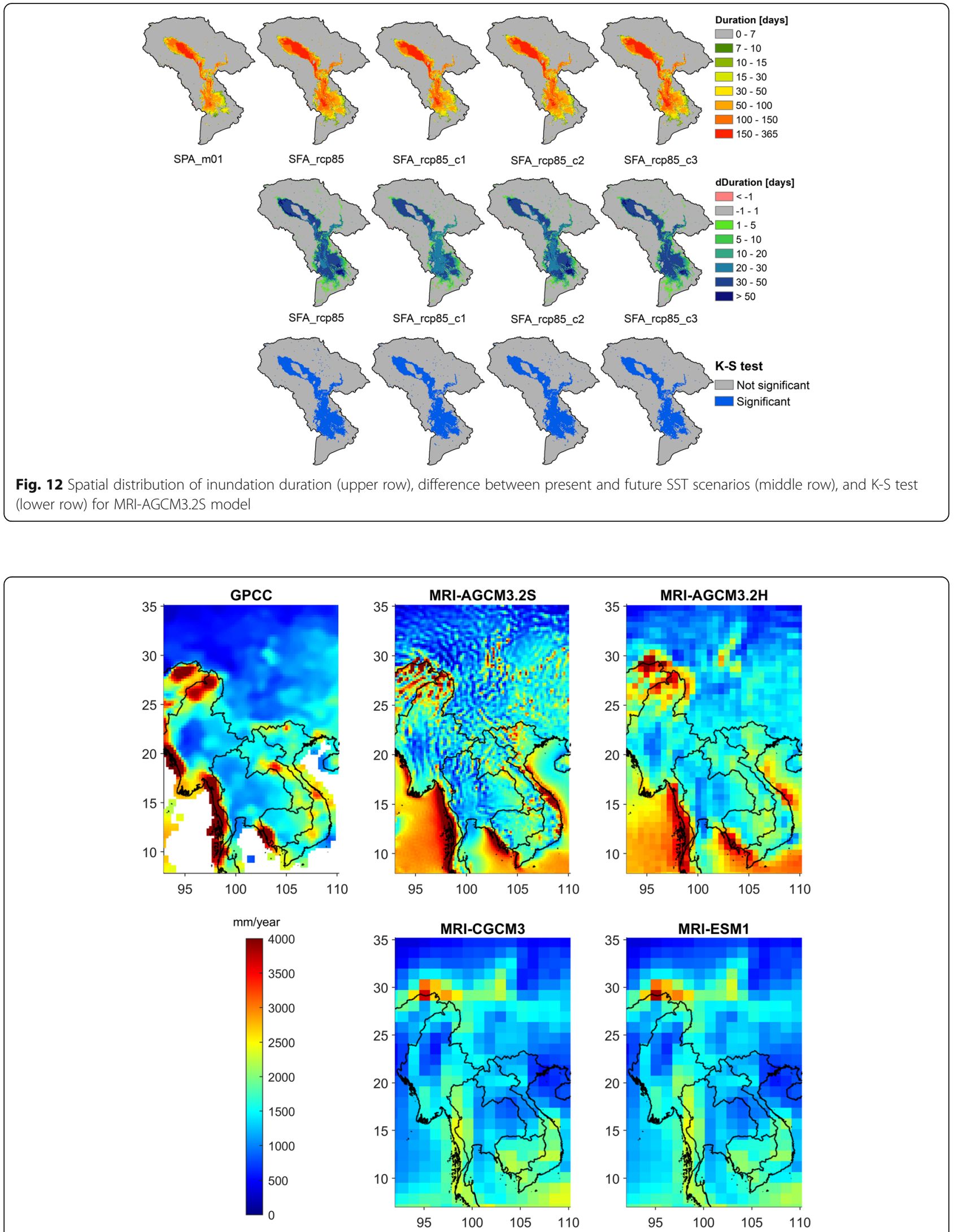

Fig. 13 Spatial distribution of annual precipitation of GPCC and four climate models (MRI-AGCM-3.2S, MRI-AGCM3.2H, MRI-CGCM3, and MRI-ESM1) 
the four models over the MRB region. The two highresolution AGCMs (MRI-AGCM3.2H and MRIAGCM3.2S) used in this showed a similar distribution while the two coarse resolution models (MRI-CGCM3 and MRI-ESM1) indicated large error, particularly in the area close the coast. This was the advantage of using observed SST as boundary condition in AGCM; however, GCMs were not able to consider this effect.

In addition, basin monthly precipitation was also compared between GPCC and four climate models without bias correction. Figure 14 showed the similarity of violin shapes between GPCC and two high-resolution AGCMs (MRI-AGCM3.2H and MRI-AGCM3.2S). The mean values range between $126-131 \mathrm{~mm}$ for AGCMs and $119-113 \mathrm{~mm}$ for GCMs comparing to $126 \mathrm{~mm}$ of GPCC. The MRI-CGCM3 and MRI-ESM1 models produced precipitation at more spread density (i.e., their median is at very low value, and top height of violin is overestimation) comparing to GPCC. Overall, two highresolution AGCMs used in this study performed better than two GCMs in CMIP5 in term of spatial and monthly precipitation in the MRB region.

\section{Implementation of climate change impact}

The results from this study clearly indicated that the river discharge and flood inundation in the MRB were significantly affected by climate change impacts. The simulation results of climate change revealed that flood inundation magnitude in the future in the LMB would be severer than the present climate. The increasing of annual precipitation (6.6-14.2\%) could force to enlarge the extreme high flow $\left(Q_{5}\right)$ at the LMB (increasing 13$30 \%$ at Kratie) and lead to increase excessive inundation in the LMB up to $19-43 \%$ for inundation area and $24-$ $55 \%$ for inundation volume. Lauri et al. (2012) determined the change in discharge at Kratie from - 10.6 to $+13.4 \%$ for A1B scenario (comparable to RCP6.0) and between -6.9 and $+8.1 \%$ for B1 scenario (comparable to RCP4.5) using five GCMs from baseline (1982-1992) to projected period (2032-2042). Västilä et al. (2010) projected annual maximum flooded area in the LMB flood pulse for 2010-2049 by changing between - 3\% and $14 \%$ in for A2 emission scenario (comparable to RCP8.5). Perera et al. (2017) found out the increasing discharge volume of $25 \%$ at Kratie in RCP8.5 scenario. Shrestha et al. (2016) analyzed the uncertainty sources of climate change on river flow in the Sekong, Sesan, and Srepok (3S) Rivers, one of the main tributary of the MRB, using three GCMs (GISS, GFDL, and IPSL) and revealed the results that peak flow was likely to increase ranging from $54.1 \%$ for RCP2.6 to $78.9 \%$ for RCP8.5 for the 2060s. The assessment results of climate change impacts on hydrological extreme flows in 11 sub-basins of the Tonle Sap Lake by Oeurng et al. (2019) using three GCM models (GFDL-CM3, GISS-E2-R-CC, and IPSLCM5A-MR) for three projected time horizons (2030s, 2060s, and 2090s) under RCP6.0 scenario revealed that most sub-basins of the Tonle Sap basin would face more extreme drought than flood.

In addition to findings of Perera et al. (2017) who studied flood inundation under SST patterns in the LMB, this study found the significant increment of flood inundation area and volume on various projected future climate change including $4 \mathrm{RCP}$ scenarios and 4 different SST patterns scenarios. More importantly, further analysis of increasing changes in flood inundation

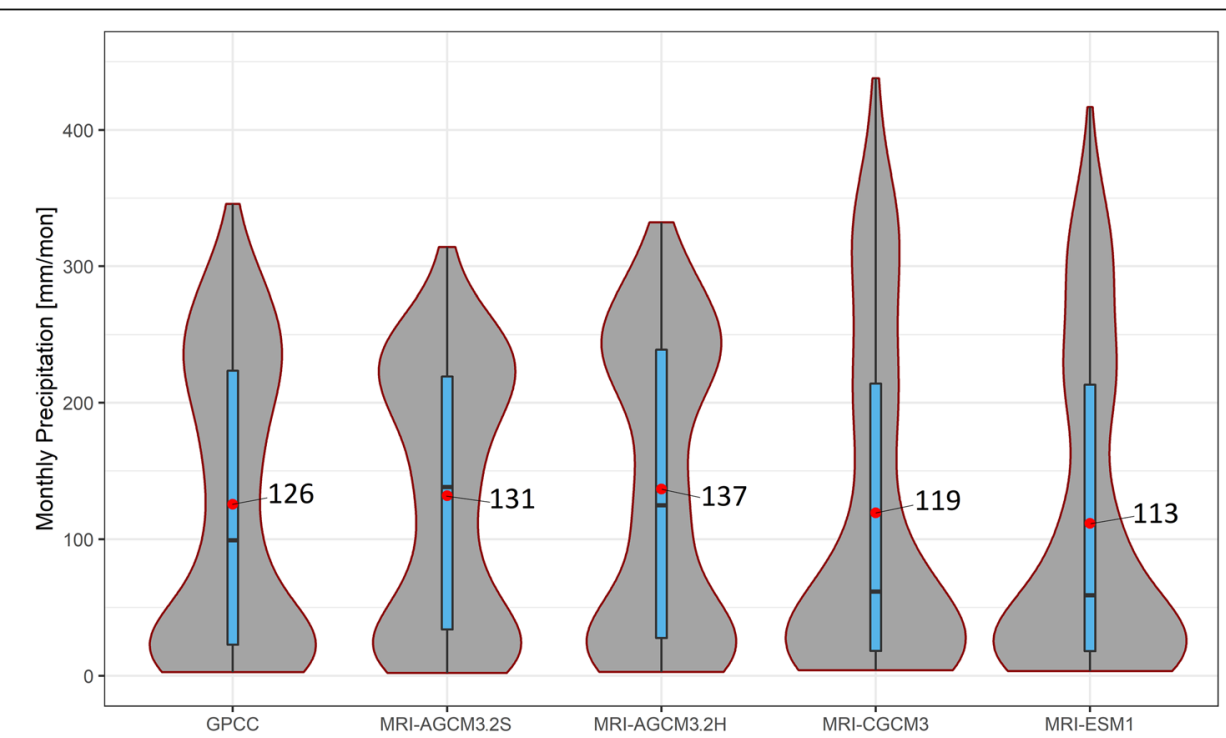

Fig. 14 Violin plot and boxplot of monthly basin precipitation of GPCC and four climate models. The red circle and black dots represent mean and median 
duration and probability was significantly determined in this study while the flood peak time would be no substantial variation.

\section{Limitations}

However, the limitation of this study was assessing only output from MRI-AGCM3.2H and MRI-AGCM3.2S. Considering more high-resolution GCMs would provide more reliability for future prediction of flood inundation. Plus, due to the limited capacity of long-term and largescale simulation, the spatial resolution of the inundation simulation in this study was taken $1.5^{\prime}$ (approx. $2.7 \mathrm{~km}$ ); therefore, the finer resolution was able to provide more accurate results. Further, the water for urban water supply, irrigation, and power generation purposes was not carried out in this study. The land-use map was taken from MODIS (year: 2000) considered as static from the present to the future. The rapid development would affect the uncertainty in the prediction. The potential effect of land-use change should be considered in future studies in the MRB.

\section{Conclusions}

This paper presented the effects of climate change on flow in the MRB and inundation in the LMB for the present (1979-2003) and the future period (2075-2099). This study compared the extreme river flow, peak inundation area, peak inundation time and volume, flood probability, and inundation duration. The analysis was conducted based on bias corrected precipitation and evapotranspiration which were outputs from two highresolution atmospheric models (MRI-AGCM3.2H $60 \mathrm{~km}$ and MRI-AGCM3.2S $20 \mathrm{~km}$ ). The result indicated that the extreme river flow and extreme flood inundation will be severer and higher magnitude at the end of the twentyfirst century for all future scenarios (RCP and SST). However, flood peak time was observed with no significant variation. The area with long flood duration corresponded with a high probability of flood inundation. This study provided additional information about climate change impacts on flood inundation for further understanding and preparing for climate change adaptation as well as flood damage reduction strategies in the LMB.

\section{Supplementary information}

Supplementary information accompanies this paper at https://doi.org/10. 1186/s40645-020-00353-z.

Additional file 1: Supplement A. Simulated and observed discharge, Supplement B. rain basin GPCC, Supplement C. rain basin AGCM20km, Supplement D. rain basin AGCM60km.

\section{Abbreviations}

2-D LIE: Two-dimensional local inertial equation; AGCM: Atmospheric general circulation model; APHRODITE: Asian Precipitation-Highly-Resolved
Observational Data Integration Towards Evaluation; CMIP5: Coupled Model Inter-comparison Project Phase 5; DEM: Digital elevation model; DOY: Days of the year; dP: Difference of probability; ET: Evapotranspiration; GFDL: Geophysical Fluid Dynamics Laboratory; GISS: The Goddard Institute for Space Studies; GPCC: Global Precipitation Climatology Centre; GSMaP: Global Satellite Mapping of Precipitation; HFA: Future data for highresolution AGCM; HPA: Present data for high-resolution AGCM; HR: Hit ratio; IPCC AR5: The Fifth Assessment Report of the Intergovernmental Panel on Climate Change; IPSL: Institut Pierre Simon Laplace; JRA-55: Japanese 55-year Reanalysis dataset; K-S: Kolmogorov-Smirnov; LMB: Lower Mekong Basin; MERIT: Multi-error-removed-improved-terrain; MODIS: Moderate-resolution imaging spectroradiometer; MRB: Mekong River Basin; MRC: Mekong River Commission; MRI: Meteorological Research Institute; NASA: National Aeronautics and Space Administration; NSE: Nash-Sutcliffe efficiency; PERSIA NN-CDR: The Precipitation Estimation from Remotely Sensed Information using Artificial Neural Networks-Climate Data Record; RCP: Representative Concentration Pathways; RMSE: Root mean square error; RRI: Rainfall-runoffinundation; SFA: Future data for super high-resolution AGCM; SPA: Present data for super high-resolution AGCM; SST: Sea surface temperature; SWAT: Soil and Water Assessment Tool; TR: True ratio; TRMM: Tropical Rainfall Measuring Mission

\section{Acknowledgements}

We thank Prof. Günter Meon for his advice and comment to improve this paper. Try S. gratefully acknowledges the travel grant from AIDA Program (Kyoto University) to attend the 2nd World Congress on Climate Change in Berlin and short research stay at Technische Universitat Braunschweig, Germany.

\section{Authors' contributions}

Try S. proposed the topic and drafted the manuscript. Sayama T. supported Try S. in the modeling process. Tanaka S. and Tanaka K. revised and supervised the methodology. Oeurng C. supported the collection of observed hydrological data. GL supported discussion the main idea and revised manuscript. All authors revised and approved the final manuscript.

\section{Funding}

This work was supported by AUN/NEED-Net (JICA) for the first author during doctoral scholarship program in Japan.

\section{Availability of data and materials}

The datasets supporting the conclusions of this article are included within the article and its supplement files.

\section{Competing interests}

The authors declare that they have no competing interest.

\section{Author details}

${ }^{1}$ Graduate School of Engineering, Kyoto University, Gokasho, Uji 611-0011, Japan. ${ }^{2}$ Disaster Prevention Research Institute, Kyoto University, Gokasho, Uji 611-0011, Japan. ${ }^{3}$ Department of Construction \& Disaster Prevention Engineering, Kyungpook National University, Gyeongsangdaero 2559, Sangju 742-711, Republic of Korea. ${ }^{4}$ Faculty of Hydrology and Water Resource Engineering, Institute of Technology of Cambodia, Russian Conf. Blvd, Phnom Penh 12156, Cambodia.

Received: 28 December 2019 Accepted: 19 July 2020

Published online: 29 July 2020

\section{References}

Arias ME, Cochrane TA, Norton D, Killeen TJ, Khon P (2013) The flood pulse as the underlying driver of vegetation in the largest wetland and fishery of the Mekong Basin. Ambio. 42(7):864-876

Arias ME, Cochrane TA, Piman T, Kummu M, Caruso BS, Killeen TJ (2012) Quantifying changes in flooding and habitats in the Tonle Sap Lake (Cambodia) caused by water infrastructure development and climate change in the Mekong Basin. J Environ Manag 112:53-66

Arnold JG, Srinivasan R, Muttiah RS, Williams JR (1998) Large area hydrologic modeling and assessment part I: model development. JAWRA Journal of the American Water Resources Association 34(1):73-89. https://doi.org/10.1111/j. 1752-1688.1998.tb05961.x 
Bates BC, Kundzewicz ZW, Wu S, Palutikof JP (2008) Climate change and water. IPCC technical paper IV. Intergovernmental Panel on Climate Change, Geneva

Beyene T, Lettenmaier DP, Kabat P (2010) Hydrologic impacts of climate change on the Nile River basin: implications of the 2007 IPCC scenarios. Clim Chang 100(3-4):433-461. https://doi.org/10.1007/s10584-009-9693-0

Friedl MA, Sulla-Menashe D, Tan B, Schneider A, Ramankutty N, Sibley A, Huang X (2010) MODIS collection 5 global land cover: algorithm refinements and characterization of new datasets. Remote Sens Environ 114(1):168-182. https://doi.org/10.1016/j.rse.2009.08.016

Intergovernmental Panel on Climate Change (IPCC) (2014) Sythesis report. Contribution of Working Groups I, II and III to the Fifth Assessment Report of the IPCC, Geneva, Switzerland

Kitoh A, Endo H (2016) Changes in precipitation extremes projected by a 20-km mesh global atmospheric model. Weather Climate Extremes 11:41-52. https://doi.org/10.1016/j.wace.2015.09.001

Kobayashi S, Ota Y, Harada Y, Ebita A, Moriya M, Onoda H, Onogi K, Kamahori H, Kobayashi C, Endo H, Miyaoka K, Takahashi K (2015) The JRA-55 reanalysis: general specifications and basic characteristics. J Meteor Soc Japan 93:5-48. https://doi.org/10.2151/jmsj.2015-001

Koponen J, Lauri H, Veijalainen N, Sarkkula J (2010). HBV and IWRM watershed modelling user guide. MRC Information and Knowledge Management Programme, DMS—Detailed Modelling Support for the MRC Project.

Kummu M, Sarkkula J, Koponen J, Nikula J (2006) Ecosystem management of the Tonle Sap Lake: an integrated modelling approach. Int J Water Resources Development 22(3):497-519. https://doi.org/10.1080/07900620500482915

Lamberts D, Koponen J (2008) Flood pulse alterations and productivity of the Tonle Sap ecosystem: a model for impact assessment. AMBIO: A Journal of the Human Environment 37(3):178-184. https://doi.org/10.1579/00447447(2008)37[178:FPAAPO]2.0.CO;2

Lauri H, Moel HD, Ward P, Räsänen T, Keskinen M, Kummu M (2012) Future changes in Mekong River hydrology: impact of climate change and reservoir operation on discharge. Hydrol Earth Syst Sci 16:4603-4619. https://doi.org/ 10.5194/hess-16-4603-2012

Li G, Zhang X, Zwiers F, Wen QH (2012) Quantification of uncertainty in highresolution temperature scenarios for North America. J Clim 25(9):3373-3389. https://doi.org/10.1175/JCLI-D-11-00217.1

Mizuta R, Arakawa O, Ose T, Kusunoki S, Endo H, Kitoh A (2014) Classification of CMIP5 future climate responses by the tropical sea surface temperature changes. SOLA. 10:167-171. https://doi.org/10.2151/sola.2014-035

Mizuta R, Yoshimura H, Murakami H, Matsueda M, Endo H, Ose T, Kamiguchi K, Hosaka M, Sugi M, Yukimoto S, Kusunoki S, Kitoh A (2012) Climate simulations using MRI-AGCM3. 2 with 20-km grid. J Meteorol Soc Jpn 90: 233-258. https://doi.org/10.2151/jmsj.2012-A12

MRC (2005) Overview of the hydrology of the Mekong Basin vol. 82. Mekong River Commission, Vientiane, Lao PDR

MRC (2010) State of the basin report 2010. Mekong River Commission, Vientiane, Lao PDR

Nigro J, Slayback D, Policelli F, Brakenridge GR (2014). NASA/DFO MODIS near real-time (NRT) global flood mapping product evaluation of flood and permanent water detection. Evaluation, Greenbelt, MD.

Oeurng C, Cochrane TA, Arias ME, Shrestha B, Piman T (2016) Assessment of changes in riverine nitrate in the Sesan, Srepok and Sekong tributaries of the lower Mekong River basin. J Hydrol Region Stud 8:95-111. https://doi.org/10. 1016/j.ejrh.2016.07.004

Oeurng C, Cochrane TA, Chung S, Kondolf MG, Piman T, Arias ME (2019) Assessing climate change impacts on river flows in the Tonle Sap Lake Basin, Cambodia. Water 11(3):618. https://doi.org/10.3390/w11030618

Perera E, Sayama T, Magome J, Hasegawa A, Iwami Y (2017) RCP8. 5-based future flood hazard analysis for the lower Mekong river basin. Hydrology 4(4):55. https://doi.org/10.3390/hydrology4040055

Sayama T, Ozawa G, Kawakami T, Nabesaka S, Fukami K (2012) Rainfall-runoffinundation analysis of the 2010 Pakistan flood in the Kabul River basin. Hydrol Sci J 57(2):298-312. https://doi.org/10.1080/02626667.2011.644245

Sayama T, Tatebe Y, Iwami Y, Tanaka S (2015) Hydrologic sensitivity of flood runoff and inundation: 2011 Thailand floods in the Chao Phraya River basin. Nat Hazards Earth Syst Sci 15:1617-1630. https://doi.org/10.5194/nhess-151617-2015

Shrestha B, Cochrane TA, Caruso BS, Arias ME, Piman T (2016) Uncertainty in flow and sediment projections due to future climate scenarios for the 35 Rivers in the Mekong Basin. J Hydrol 540:1088-1104. https://doi.org/10.1016/j.jhydrol. 2016.07.019

Tanaka T, Yoshioka H, Siev S, Fujii H, Fujihara Y, Hoshikawa K, Ly S, Yoshimura C (2018) An integrated hydrological-hydraulic model for simulating surface water flows of a shallow Lake surrounded by large floodplains. Water 10(9): 1213. https://doi.org/10.3390/w10091213

Taylor KE, Stouffer RJ, Meehl GA (2012) An overview of CMIP5 and the experiment design. Bull Am Meteorol Soc 93(4):485-498

Try S, Lee G, Yu W, Oeurng C (2019) Delineation of flood-prone areas using geomorphological approach in the Mekong River basin. Quat Int 503:79-86. https://doi.org/10.1016/j.quaint.2018.06.026

Try S, Lee G, Yu W, Oeurng C, Jang C (2018) Large-scale flood-inundation modeling in the Mekong River basin. J Hydrol Eng 23(7):05018011. https:// doi.org/10.1061/(ASCE)HE.1943-5584.0001664

Try S, Tanaka S, Tanaka K, Sayama T, Oeurng C, Uk S, Takara K, Hu M, Han D (2020) Comparison of various gridded precipitation datasets for rainfall-runoff and inundation modeling in the Mekong River basin. PLoS One 15(1). https://doi.org/10.1371/journal.pone.0226814

Uk S, Yoshimura C, Siev S, Try S, Yang H, Oeurng C, Li S, Hul S (2018) Tonle Sap Lake: current status and important research directions for environmental management. Lakes Reserv Res Manag 23(3):177-189. https://doi.org/10. 1111//re.12222

Västilä K, Kummu M, Sangmanee C, Chinvanno S (2010) Modelling climate change impacts on the flood pulse in the lower Mekong floodplains. J Water Climate Change 1(1):67-86. https://doi.org/10.2166/wcc.2010.008

Wang S, Jiao S, Xin H (2013) Spatio-temporal characteristics of temperature and precipitation in Sichuan Province, southwestern China, 1960-2009. Quat Int 286:103-115. https://doi.org/10.1016/j.quaint.2012.04.030

Wu F, Wang X, Cai Y, Li C (2016) Spatiotemporal analysis of precipitation trends under climate change in the upper reach of Mekong River basin. Quat Int 392:137-146. https://doi.org/10.1016/j.quaint.2013.05.049

Yamazaki D, Ikeshima D, Tawatari R, Yamaguchi T, O'Loughlin F, Neal JC, Sampson CC, Kanae S, Bates PD (2017) A high accuracy map of global terrain elevations. Geophys Res Lett 44:5844-5853. https://doi.org/10.1002/ 2017GL072874

\section{Publisher's Note}

Springer Nature remains neutral with regard to jurisdictional claims in published maps and institutional affiliations.

\section{Submit your manuscript to a SpringerOpen ${ }^{\circ}$ journal and benefit from:}

- Convenient online submission

- Rigorous peer review

- Open access: articles freely available online

High visibility within the field

- Retaining the copyright to your article

Submit your next manuscript at $>$ springeropen.com 